\title{
Histology and Renal Lipoperoxidation in Rats Exercised on a Treadmill and Submitted to Water Restriction
}

\author{
Histología y Lipoperoxidación Renal en Ratas Ejercitadas sobre \\ una Caminadora y Sometidas a Restricción de Agua
}

\author{
Roselene Modolo Regueiro Lorençoni*; Elisa Bizetti Pelai**; Moacir Fernandes Godoy ${ }^{* * *}$; Alice Cristina Antonio \\ dos Santos $^{* * * *}$; Lívia Hissae Miyoshi ${ }^{* * * *}$; Rebeca Nicolás Paronetto de Oliveira ${ }^{* * * * *}$; Carlos Roberto

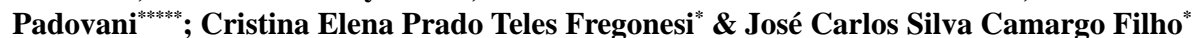

LORENÇONI, R. M. R.; PELAI, E. B.; GODOY, M. F.; DOS SANTOS, A. C. A.; MIYOSHI, L. H.; DE OLIVEIRA, R. N. P.; PADOVANI, C. R.; FREGONESI, C. E. P. T. \& CAMARGO FILHO, J. C. S. Histology and renal lipoperoxidation in rats exercised on a treadmill and submitted to water restriction. Int. J. Morphol., 33(2):660-665, 2015.

SUMMARY: Physical effort stimulates an increase in oxygen consumption in tissues, generating toxic chemical species derived from oxygen (ROS), which are considered the initiators of the lipid peroxidation process (LPO), the major mechanism of cellular injury. As the essential mechanism for maintaining the electrolyte balance depends on an effective kidney function, oxidative stress in this organ can be a key factor in the development and persistence of hypertension. This study aimed to determine the kidney changes induced by a combination of fluid restriction and exercise in rats. The study consisted of 24 male Wistar rats of 90 days of age, divided into four groups, two of which were submitted to water restriction and exercise on a treadmill. Twenty-four hours after the last training session, the animals were euthanized and the left kidney was removed. The upper part of the kidney was used for the histological procedures and the lower part for the quantification of membrane lipoperoxides. Analysis of variance was applied after testing the normality of data, and the comparison between groups was performed using the Bonferroni test, adopting a significance of $p<0.05$. The restriction had an influence on body weight; kidney weight; proximal tubule maximum diameter; and area, perimeter and diameter of glomeruli, whereas the exercise affected the weight and the minimum diameter of the proximal tubule. According to the TBARS (thiobarbituric acid reactive substances) method, there was a difference between the G1 (control) and G3 (sedentary with water restriction) and between the G2 (exercised with water) and G4 (exercised with water restriction) compared to G1. The treadmill exercise combined with the water restriction promoted structural changes in the glomeruli and promoted oxidative stress, although neither variable corroborated for the potentiating of lipid peroxidation.

KEY WORDS: Morphology; Oxidative Stress; Kidney.

\section{INTRODUCTION}

Physical exercise induces increased energy demands from tissues and organs in the body which stimulates them to increase their oxygen consumption and thus the formation of toxic chemical species derived from oxygen (ROS) (Deminice et al., 2009; Packer et al., 2008). These toxic chemical species, by reacting with polyunsaturated fatty acids are considered to be the initiators of the process of the lipid peroxidation (LPO) mechanism which changes the permeability of membranes, inducing the formation of hydrophilic pores, one of the major mechanisms of cell damage (Tucci Junior et al., 2008).
During exercise, as well as in situations involving increased cellular metabolism, there is a tendency to increased production of ROS (Packer et al.), which when excessive configures the oxidative stress (Wilcox \& Gutterman, 2005). It is known that water makes up about $60 \%$ of the human body and comes from both exogenous (food and fluid intake) and endogenous (oxidation of macronutrients) sources, offering an amount of water corresponding to the daily losses so that the homeostasis of the organism is maintained (Carvalho \& Mara, 2010; Jéquier \& Constant, 2010).

\footnotetext{
* Doctor Professor of the Physiotherapy Department at the University of Science and Technology FCT, Universidad Estatal Paulista, Presidente Prudente, Brazil.

** Postgraduate student of Stricto Sensu in physiotherapy from the University of Science and Technology FCT, Universidad Estatal Paulista, Presidente Prudente, Brazil.

**** Faculty of Medicine of São José do Rio Preto, São José do Rio Preto, Brazil.

***** Graduate physiotherapist from the University of Science and Technology FCT, Universidad Estatal Paulista, Presidente Prudente, Brazil.

****** Department of Biostatistics, Institute of Biosciences, Universidad Estatal Paulista, Botucatu, Brazil.
} 
LORENÇONI, R. M. R.; PELAI, E. B.; GODOY, M. F.; DOS SANTOS, A. C. A.; MIYOSHI, L. H.; DE OLIVEIRA, R. N. P.; PADOVANI, C. R.; FREGONESI, C. E. P. T. \& CAMARGO FILHO, J. C. S. Histology and renal lipoperoxidation in rats exercised on a treadmill and submitted to water restriction. Int. J. Morphol., 33(2):660-665, 2015.

The loss of water (kidney, skin, respiratory tract and digestive system) is directly dependent on the ambient temperature and the intensity of physical activity. When compensated for with water intake, there is the benefit of thermoregulation, facilitating the transfer of heat. If not, there is depletion of water, electrolytes and glycogen, thereby generating dehydration (Carvalho \& Mara; Jéquier \& Constant). However, the essential mechanism for the maintenance of fluid and electrolyte balance depends on proper functioning kidneys (Carvalho \& Mara).

Mild dehydration of 1-2\% loss of body weight can lead to loss of cognitive and physical function (Carvalho \& Mara; Jéquier \& Constant; Murray, 2007). From this point on, there is an increase of $0.4{ }^{\circ} \mathrm{C}$ in body temperature with every subsequent hydration percentage. With a $3 \%$ loss there is a significant drop in performance, between 4 and $6 \%$ there may be thermal fatigue and above $6 \%$ a risk of thermal shock, coma and even death (Carvalho \& Mara).

Oxidative stress in the kidney may be a key factor in the development and persistence of hypertension. This is of increasing importance, as all cardiovascular risk factors, in clinical studies and experiments, have been associated with evidence of increased ROS, which may be linked not only to vasoconstriction, salt retention and hypertension, but also to activation of inflammatory mediators such as nuclear factor- $\mathrm{B}$, which is connected to causing cellular inflammation and cytokine production accession, considered key points in the pathophysiology of chronic cardiovascular and kidney diseases (Wilcox \& Gutterman).

Considering the above, the present study aimed to evaluate the effect of fluid restriction on the kidney tissue of rats subjected to physical exercise on a treadmill, taking into consideration oxidative stress, morphological and morphometric changes of glomeruli, proximal convoluted tubule and distal convoluted tubule.

\section{MATERIAL AND METHOD}

The study consisted of 24 male Wistar rats of 90 days of age from the Central Animal Facility of UNESP - Botucatu which were housed in the vivarium of the FCT/UNESP Faculty of Science and Technology - President Prudente Campus, where they remained throughout the experiment. This study was approved by the Committee of Ethics and Research from the Faculty of Science and Technology FCT/UNESP (Case nos. 209/2007 and 252/2008).

The animals were randomized into four groups
(Table I). The groups with water restriction were housed in individual cages, while the other animals were kept in collective plastic cages each containing six animals. Room temperature was maintained at $22+3{ }^{\circ} \mathrm{C}$ with 12 -h cycles of light. Fluid intake was recalculated weekly and restricted to $30 \%$ of the total water usually ingested in $24 \mathrm{~h}$ (McArdle et al., 2008).

Table I. Division of animals into groups.

\begin{tabular}{ll}
\hline Groups $(\mathbf{n}=\mathbf{6})$ & \multicolumn{1}{c}{ Description } \\
\hline G1 & Control Group \\
G2 & Exercised Group with water ad libitum \\
G3 & Sedentary Group with Water Restriction \\
G4 & Exercised Group with Water Restriction \\
\hline
\end{tabular}

The animals in the trained groups (G2 and G4) underwent exercises on a treadmill, including one week of adaptation (sessions with progressive duration) and training sessions (60 min), where the animals walked at $9.75 \mathrm{~m}$ per minute for five weeks, considered as moderate exercise intensity.

After twenty-four hours of the last training session, the animals were euthanized by decapitation using a guillotine; the left kidney was removed, weighed and sectioned transversely through its long axis, near the renal hilum. The upper part was used for histological procedures, cuts of six $\mu \mathrm{m}$ were obtained, stained with Hematoxolinaeosin (HE) and then subjected to analysis using optical microscopy, which enabled the assessment of the renal architecture (glomerulus, proximal convoluted tubule and distal convoluted tubule ). From each animal, 20 samples of each structure were studied, totaling 120 structures per group, using Image Pro-Plus software, to measure area, perimeter and diameter (maximum, medium and minimum).

The lower portion of the kidney was immersed in liquid nitrogen for freezing and used for the quantification of membrane lipoperoxides. To this end, the kidney homogenate and supernatant were obtained using the thiobarbituric acid (TBARS) (Cechini et al., 1990) method.

The data obtained by histomorphometry were analyzed using descriptive statistics. According to the nature of the variables, analysis of variance was applied to the schema of two factors in a complete randomized design. As for the TBARS method the Kolmogorov-Smirnov test was performed to verify the Gaussian distribution and applied analysis of variance for the two-factor scheme. The comparison between groups was performed using the Bonferroni test. For all tests the significance level was set at $\mathrm{p}<0.05$. 


\section{RESULTS}

The results obtained in this study were analyzed regarding the generalities observed during the experiments, the animals' body weight, kidney weight, organelles and analysis of quantification lipoperoxides in these organs.

Body Weight: There was a significant difference for the variable water restriction between the exercised groups $(\mathrm{G} 2$ and G4) at two different moments: week 1 and at sacrifice. As for the exercise variable a difference was observed in the body weight of the groups with fluid restriction (G3 and G4) at week 1 (Table II).

Kidney Weight: Table III presents the mean and standard deviation of the kidney weights of each group obtained immediately after euthanasia. It appears that only the variable water restriction showed a significant interaction between the groups and the control.

Organelles: It was observed that the exercise variable showed no significant effect on the area and the perimeter of the organelles studied. However, fluid restriction showed a significant difference in the area of glomeruli between the sedentary groups (G1 and G3) and the exercise groups (G2 and G4). Regarding the perimeter, a difference was noted in the glomeruli of the sedentary groups (G1 and G2) (Table IV).

As regards the maximum, minimum and average diameters of organelles, a significant difference was noted in the maximum diameter of the proximal tubule between the G2 and G4 and the glomeruli between the G1 and G3, and the minimum diameter of the glomeruli $\mathrm{G} 2$ and $\mathrm{G} 4$; and the average diameter of glomeruli between the sedentary (G1 and G3) and exercised (G2 and G4) groups due to fluid restriction. However, there was a significant difference in the minimum diameter of the proximal tubule in the exercised group between the groups with restricted fluid intake (G3 and G4) (Table V) (Fig. 1).

Analysis and quantification of lipoperoxides (TBARS): According to the TBARS method, we observed significant differences in the comparison between the sedentary groups $(\mathrm{G} 1$ and $\mathrm{G} 3, \mathrm{t}=3.06$ and $\mathrm{p}<0.001)$ and between the exercise groups and G1 (Table VI).

Table II. Weights of animals according to water restriction and exercise.

\begin{tabular}{lcccc}
\hline Group & Baseline & Week 1 & Week 2 & Pre-Sacrifice \\
\hline G1 & $233.83 \pm 14.11$ & $254.67 \pm 12.26$ & $300.50 \pm 14.86$ & $305.33 \pm 19.18$ \\
G2 & $250.00 \pm 25.39$ & $273.00 \pm 27.39^{\text {a }}$ & $325.83 \pm 35.23$ & $344.83 \pm 36.50^{\text {a }}$ \\
G3 & $217.50 \pm 34.35$ & $220.00 \pm 26.44^{\mathrm{A}}$ & $237.17 \pm 27.50$ & $268.50 \pm 35.68$ \\
G4 & $244.67 \pm 16.73$ & $247.50 \pm 12.63^{\text {aA }}$ & $254.50 \pm 16.15$ & $296.50 \pm 21.27^{\text {a }}$ \\
\hline
\end{tabular}

$\mathrm{a}, \mathrm{b}=$ Equal lowercase letters indicate statistically significant differences regarding fluid restriction (Analysis of variance for the schema of two factors, $\mathrm{p}>0.05$ ).

$\mathrm{A}, \mathrm{B}=$ Equal uppercase letters indicate statistically significant differences regarding exercise (analysis of variance for two-factor scheme, $\mathrm{p}>0.05$ ).

Table III. Weights of kidneys of animals according to water restriction and exercise.

\begin{tabular}{lcc}
\hline Group & Kidney weight & Sedentary \\
\hline Restriction & $0.881 \pm 0.073^{\mathrm{a}}$ & $0.790 \pm 0.072 \mathrm{a}$ \\
Ad Libitum & $1.025 \pm 0.123$ & $0.931 \pm 0.091$ \\
\hline
\end{tabular}

$\mathrm{a}=$ Statistically significant difference when compared to the ad libitum group (Analysis of Variance for the schema of two factors, $\mathrm{p}>0.05$ ).

Table IV. Area and perimeter according to fluid restriction and exercise.

\begin{tabular}{llccc}
\hline Variable & Group & Proximal Tubule & Distal Tubule & Glomerulus \\
\hline Area & G1 & $37.40 \pm 6.62$ & $15.69 \pm 2.20$ & $6708.15 \pm 667.23^{\mathbf{a}}$ \\
& G2 & $35.32 \pm 5.51$ & $15.07 \pm 2.00$ & $6448.35 \pm 531.72^{\mathbf{a}}$ \\
& G3 & $32.53 \pm 5.77$ & $14.62 \pm 2.90$ & $5639.72 \pm 327.53 \mathbf{~ b}$ \\
Perimeter & G4 & $32.97 \pm 3.36$ & $15.52 \pm 1.89$ & $5744.00 \pm 874.45^{\mathbf{b}}$ \\
& G1 & $28.76 \pm 3.41$ & $14.91 \pm 1.05$ & $305.55 \pm 18.78^{\mathbf{b}}$ \\
& G2 & $27.55 \pm 2.47$ & $14.54 \pm 0.99$ & $298.59 \pm 12.36^{\mathbf{b}}$ \\
& G3 & $26.43 \pm 2.29$ & $14.26 \pm 1.33$ & $280.81 \pm 7.03$ \\
& G4 & $24.56 \pm 1.64$ & $14.70 \pm 0.84$ & $278.01 \pm 21.24$ \\
\hline
\end{tabular}

$\mathrm{a}, \mathrm{b}=$ Equal letters show statistically significant differences in fluid restriction (Analysis of Variance for the schema of two factors in a randomized scheme, $\mathrm{p}>0.05$ ). 
LORENÇONI, R. M. R.; PELAI, E. B.; GODOY, M. F.; DOS SANTOS, A. C. A.; MIYOSHI, L. H.; DE OLIVEIRA, R. N. P.; PADOVANI, C. R.; FREGONESI, C. E. P. T. \& CAMARGO FILHO, J. C. S. Histology and renal lipoperoxidation in rats exercised on a treadmill and submitted to water restriction. Int. J. Morphol., 33(2):660-665, 2015.

Table V. Diameters according to fluid restriction and exercise.

\begin{tabular}{lcccc}
\hline Variable & Group & Proximal Tubule & Distal Tubule & Glomerulus \\
\hline Maximum & G1 & $10.89 \pm 1.33$ & $5.22 \pm 0.33$ & $106.98 \pm 6.31 \mathbf{b}$ \\
diameter & G2 & $10.65 \pm 1.04^{\mathbf{a}}$ & $5.18 \pm 0.41$ & $103.54 \pm 3.94$ \\
& G3 & $10.36 \pm 0.88$ & $4.97 \pm 0.55$ & $98.42 \pm 2.43^{\mathbf{b}}$ \\
& G4 & $9.41 \pm 0.76^{\mathbf{a}}$ & $5.20 \pm 0.35$ & $95.80 \pm 7.31$ \\
Minimum & G1 & $3.64 \pm 0.38$ & $3.60 \pm 0.33$ & $75.46 \pm 4.07$ \\
diameter & G2 & $3.57 \pm 0.22$ & $3.57 \pm 0.26$ & $76.13 \pm 4.57^{\mathbf{a}}$ \\
& G3 & $3.35 \pm 0.35 \mathrm{~A}$ & $3.55 \pm 0.35$ & $69.44 \pm 2.60$ \\
Average & G4 & $3.87 \pm 0.12 \mathrm{~A}$ & $3.65 \pm 0.19$ & $72.35 \pm 5.97^{\mathbf{a}}$ \\
diameter & G1 & $7.33 \pm 0.85$ & $4.41 \pm 0.28$ & $90.90 \pm 4.57^{\mathbf{a}}$ \\
& G2 & $7.17 \pm 0.56$ & $4.33 \pm 0.28$ & $89.17 \pm 3.69^{\mathbf{b}}$ \\
& G3 & $6.90 \pm 0.56$ & $4.24 \pm 0.42$ & $83.97 \pm 6.40^{\mathbf{a}}$ \\
& G4 & $6.72 \pm 0.48$ & $4.38 \pm 0.25$ & $83.45 \pm 2.18^{\mathbf{b}}$ \\
\hline
\end{tabular}

$\mathrm{a}, \mathrm{b}=$ Equal letters show statistically significant differences in fluid restriction (Analysis of Variance for the schema of two factors in a randomized scheme, $p>0.05$ )

$\mathrm{A}=$ Equal letters demonstrate statistically significant differences in exercise (Analysis of Variance for the schema of two factors in a randomized scheme, $\mathrm{p}>0.05$ ).

Table VI. Quantification of membrane Lipoperoxides (TBARS).

\begin{tabular}{lcc}
\hline Group & Average & $\begin{array}{c}\text { Standard } \\
\text { deviation }\end{array}$ \\
\hline G1 & $1.507^{\text {abc }}$ & 0.458 \\
G2 & $4.116 \mathrm{a}$ & 1.259 \\
G3 & $4.569 \mathrm{~b}$ & 1.080 \\
G4 & $4.428^{\mathbf{c}}$ & 0.853 \\
\hline
\end{tabular}

Equal letters represent statistically significant differences: $\mathrm{t}=$ 2.60 and $\mathrm{p}<0.03 ; \mathrm{bt}=3.06$ and $\mathrm{p}<0.001 ; \mathrm{ct}=2.92, \mathrm{P}<0.01$.

\section{DISCUSSION}

It is known that physical exercise alters the homeostatic mechanisms due to increased metabolic activity, unleashing an energy demand, which consequently produces changes from hormonal secretions to body development (Packer et al.). The relationship between exercise and gain and loss of body weight is directly related to nutrition and intensity of effort.

Malnutrition, as well as water or food restriction causes reduction in weight of the animal exercised, with a tendency for a gradual and progressive decrease (Prazeres et al., 2004; Tomanari et al., 2003).

In the present study, all animals showed an increase in body weight over time, demonstrating that fluid restriction did not affect growth. However, it was observed that despite the lack of statistical significance, the groups submitted to water restriction (G3 and G4) had significantly lower body weight compared to the groups with water ad libitum (G1 and G2).

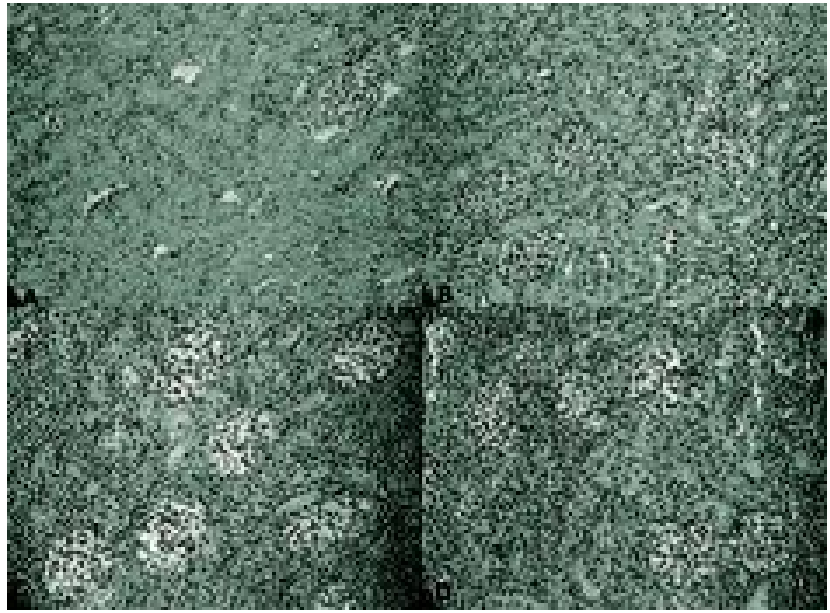

Fig. 1 Images of the kidneys of the rats. 20x. A. G3 (Sedentary group with water restriction); B. G4 (Exercise group with fluid restriction; C. G1 (Control group); D. G2 (Exercise group with water ad libitum).

Studies on the influence of exercise on the human body (Almeida, 2007; Lizardo et al., 2007), and also in animals (Camargo Filho et al., 2005; Araújo et al., 2009; Masi \& Silva, 2009) are diverse and well disseminated, but regarding experiments on fluid restriction, reports are scarce, specifically in relation to animal experiments (Prazeres $e t$ al.; Tomanari et al., 2003, 2007).

The difficulties encountered in the study concerning the exercise associated with fluid restriction, reiterate the importance of research involving renal tissue, since this is one of the first organs to be influenced by electrolyte changes. In this sense, the present study sought to determine possible changes induced by the combination of exercise and fluid restriction. 
In one study, to verify changes in kidneys of fetuses following administration of diluted aspartame in pregnant rats, a significant increase in glomerular volume and the nuclear size of cells in the distal and proximal convoluted tubules and the collecting duct (Martins \& Azoubel, 2006). However, in the present study significant changes were not observed in the structures analyzed, which could be due to the short time of exposure to water restriction, with an adaptation of the animal's body to the condition.

As oxidative phosphorylation increases in response to exercise, the formation of ROS is incremented. In studying the effects of oxidative stress caused by exercise, it was noted that there was an increase in acute exercise on levels of malondialdehyde (MDA) (Arslan et al., 2005). In contrast, the restriction of water intake is also capable of producing oxidative stress in the body.

It was expected that the combination of the two factors would reflect in higher levels of circulating ROS when compared to the factors in isolation, which did not occur. Fluid restriction, both isolated and associated with exercise was able to generate oxidative stress, but the isolated water restriction was more effective in this regard.

The exercise performed on a treadmill associated with fluid restriction promoted structural changes in the glomeruli and promoted oxidative stress, but the association of the variables did not substantiate the enhancement of lipid peroxidation.

LORENÇONI, R. M. R.; PELAI, E. B.; GODOY, M. F.; DOS SANTOS, A. C. A.; MIYOSHI, L. H.; DE OLIVEIRA, R. N. P.; PADOVANI, C. R.; FREGONESI, C. E. P. T. \& CAMARGO FILHO, J. C. S. Histología y lipoperoxidación renal en ratas ejercitadas sobre una caminadora y sometidas a restricción de agua. Int. J. Morphol., 33(2):660-665, 2015.

RESUMEN: El esfuerzo físico estimula un aumento en el consumo de oxígeno en los tejidos, generando variedades químicas tóxicas derivadas de oxígeno (ROS), que son considerados iniciadores del proceso de peroxidación lipídica (LPO), principal mecanismo de lesión celular. Como el mecanismo esencial para mantener el equilibrio de los electrolitos depende de una función renal eficaz, el estrés oxidativo en este órgano puede ser un factor clave en el desarrollo y persistencia de la hipertensión. Este estudio tuvo como objetivo determinar los cambios renales en ratas, inducidos por una combinación de restricción de líquidos y ejercicio. Esta investigación se realizó en 24 ratas Wistar machos de 90 días de edad, divididos en cuatro grupos, dos de los cuales fueron sometidos a restricción de agua, mientras que los dos grupos restantes fueron ejercitados en una caminadora. Veinticuatro horas después de la última sesión de entrenamiento, los animales fueron sacrificados y se realizó la extracción del riñón izquierdo. La parte superior del riñón se usó para los procedimientos histológicos y la parte inferior para la cuantificación de peróxidos lipídicos en la membrana. El análisis de varianza se aplicó después de probar la normalidad de los datos, y la comparación entre grupos se realizó mediante la prueba de Bonferroni, adoptando una significación de p <0,05. La restricción hídrica tuvo influencia sobre: el peso corporal, peso de los riñones, diámetro máximo del túbulo proximal, y área, perímetro y diámetro de los glomérulos. Mientras que el ejercicio afectó el peso y el diámetro mínimo del túbulo proximal de las ratas. Según el método SRAT (sustancias reactivas al ácido tiobarbitúrico), existió una diferencia entre el G1 (control) y G3 (sedentarismo con restricción de agua) y entre el G2 (ejercicio con agua) y G4 (ejercicio con restricción de agua) en comparación con G1. El ejercicio rodante combinado con la restricción de agua promovió cambios estructurales en los glomérulos y estimuló el desarrollo de estrés oxidativo, aunque ninguna variable fue corroborada para establecer la potenciación de la peroxidación lipídica.

PALABRAS CLAVE: Morfología; Estrés Oxidativo; Riñón.

\section{REFERENCES}

Almeida, M. B. Frequência Cardíaca e Exercício: Uma interpretação baseada em evidências. Rev. Bras. Cineantropom. Desempenho Hum., 9(2):196-202, 2007.

Araújo, M. B.; Manchado-Gobatto, F. B.; Voltarelli, F. A.; Ribeiro, C.; Mota, C. S. A.; Gobatto, C. A. \& de Melo, M. A. R. Efeitos do treinamento de corrida em diferentes intensidades sobre a capacidade aeróbia e produção de lactato pelo músculo de ratos Wistar. Rev. Bras. Med. Esporte, 15(5):365-9, 2009.

Arslan, C.; Gulcu, F. \& Gursu, M. F. Effects of oxidative stress caused by acute and regular exercise on levels of some serum metabolites and the activities of paraoxonase and arylesterase. Biol. Sport, 22(4):375-83, 2005.
Camargo Filho, J. C. S.; Vanderlei, L. C. M.; Camargo, R. C. T.; Oliveira, D. A. R.; Oliveira Júnior, A. S.; Dal Pai, V. \& Belangero, W. D. Análise histológica, histoquímica e morfométrica do músculo sóleo de ratos submetidos a treinamento físico em esteira rolante. Arq. Ciênc. Saúde, 12(4):196-9, 2005.

Carvalho, T. \& Mara, L. S. Hidratação e Nutrição no Esporte. Rev. Bras. Med. Esporte, 16(2):144-8, 2010.

Cechini, R.; Aruoma, O. I. \& Halliwell, B. The action of hydrogen peroxide on the formation of thiobarbituric acid-reactive material from microsomes, liposomes or from DNA damaged by bleomycin or phenanthroline. Artefacts in the thiobarbituric acid test. Free Radic. Res. Commun., 10(4-5):245-58, 1990. 
LORENÇONI, R. M. R.; PELAI, E. B.; GODOY, M. F.; DOS SANTOS, A. C. A.; MIYOSHI, L. H.; DE OLIVEIRA, R. N. P.; PADOVANI, C. R.; FREGONESI, C. E. P. T. \& CAMARGO FILHO, J. C. S. Histology and renal lipoperoxidation in rats exercised on a treadmill and submitted to water restriction. Int. J. Morphol., 33(2):660-665, 2015.

Deminice, R.; Degiovanni, G. C.; Garlipp-Picchi, M. R.; Nóbrega, M. T.; Teixeira, M. \& Jordão, A. A. Evolução de biomarcadores de estresse oxidativo e relação com a performance competitiva em dois momentos da temporada de treinamento de natação. Rev. Bras. Med. Esporte, 15(4):27781,2009

Jéquier, E. \& Constant, F. Water as an essential nutrient: the physiological basis of hydration. Eur. J. Clin. Nutr., 64(2):115-23 2010.

Lizardo, J. H. F.; Modesto, L. K.; Campbell, C. S. G. \& Simões, H. G. Hipotensão pós-exercício: comparação entre diferentes intensidades de exercício em esteira ergométrica e cicloergômetro. Rev. Bras. Cineantropom. Desempenho Hum., 9(2):115-20, 2007.

McArdle, W. D.; Katch, F. I. \& Katch, V. L. Fisiologia do exercício. energia, nutrição e desempenho humano. $6^{\mathrm{a}}$ ed. Río de Janeiro, Guanabara Koogan, 2008.

Martins, M. R. I. \& Azoubel, R. Efeitos do aspartame no rim fetal de ratos-estudo cariométrico. J. Bras. Nefrol., 28(3):151-7, 2006.

Masi, L. N \& Silva, E. P. P. A influência dos ácidos graxos trans na disfunção da célula endotelial e o possível efeito terapêutico do exercício sobre o tecido endotelial como forma de prevenção ou regressão da aterosclerose. J. Vasc. Bras., 8(2):171-6, 2009.

Murray, B. Hydration and physical performance. J. Am. Coll. Nutr., 26(5 Suppl.):542S-8S, 2007.

Packer, L.; Cadenas, E. \& Davies, K. J. Free radicals and exercise: an introduction. Free Radic. Biol. Med., 44(2):123-5, 2008.

Prazeres, F. G.; Pessoa, D. C. N. P.; Bion, F. M. \& Arnauld, T. M. S. Exercício Físico, Crescimento e Desenvolvimento: Estudo em ratos jovens desnutridos pela dieta básica regional (DBR) e recuperados nutricionalmente. Rev. Bras. Educ. Fis. Esp., 18(1):7-16, 2004.

Tomanari, G. Y.; Amaral, V. L. A. R.; Ramos, K. P.; Sabino, N. D. M.; Geremias, M. C. G.; Sanches, L. C. \& Albino, A. B. Parâmetros generalizados de operações de privação por restrições hídrica e alimentar em ratos machos Wistar. Acta Comport., 15(2):131-45, 2007.

Tomanari, G. Y.; Pine, A. S. \& Silva, M. T. A. Ratos Wistar sob regimes rotineiros de restrição hídrica e alimentar. Rev. Bras. Ter. Comport. Cognit., 5(1):57-71, 2003.

Tucci Junior, S.; Carvalho, R. M.; Celini, F. M.; Cologna, A. J.; Suaid, H. J.; Tirapelli, L. F. \& Martins, A. C. Renal ischemia and reperfusion injury: influence of chorpromazine on renal function and lipid peroxidation. Acta Cir. Bras., 23 (Suppl. 1):42-6, 2008.
Wilcox, C. S. \& Gutterman, D. Focus on oxidative stress in the cardiovascular and renal systems. Am. J. Physiol. Heart Circ. Physiol., 288(1):H3-6, 2005.

\author{
Correspondence to: \\ Roselene Modolo Regueiro Lorençoni \\ Rua Getúlio Pinheiro \\ 136 - Vila Coronel Goulart \\ CEP: $19020-270$ \\ Presidente Prudente \\ São Paulo \\ BRASIL
}

Email: roselene@fct.unesp.br

Received: 01-07-2014

Accepted: 04-03-2015 